\title{
A Case of Silicone Granuloma in the Neck
}

\author{
Sang Ha Lee ${ }^{1}$ and Seung Hoon Woo ${ }^{1,2}$ \\ ${ }^{1}$ Department of Otorhinolaryngology-Head and Neck Surgery, ${ }^{2}$ Institute of Health Sciences, School of Medicine, \\ Gyeongsang National University, Jinju, Korea
}

\section{경부 실리콘 육아종 1 예}

\author{
이 상 하 ${ }^{1}$ 우 승 훈 ${ }^{1,2}$ \\ 경상대학교 의학전문대학원 이비인후과학교실, ${ }^{1}$ 건강과학연구원 ${ }^{2}$
}

\author{
Received June 27, 2014 \\ Revised July 23, 2014 \\ Accepted August 2, 2014 \\ Address for correspondence \\ Seung Hoon Woo, MD \\ Department of Otorhinolaryngology- \\ Head and Neck Surgery, \\ School of Medicine, \\ Gyeongsang National University, \\ 79 Gangnam-ro, \\ Jinju 660-702, Korea \\ Tel $+82-55-750-8178$ \\ Fax $+82-55-759-0613$ \\ E-mail lesaby@hanmail.net
}

\begin{abstract}
Liquid injectable silicone has been used extensively in some countries during the past 5 decades for soft tissue augmentation. Although considered biologically inert, this material has been reported as potentially inducing, after tissue injection, a granulomatous inflammatory response of variable severity. A 73-year-old female patient visited our clinic with neck masses and pain. Her past medical history revealed a face and neck augmentation with silicone about 15 years ago by unqualified medical personnel. Because of the persistent superficial neck pain, we removed the palpated neck masses detected by physical examination and computed tomography. Histopathologic test confirmed silicone granuloma. The neck pain disappeared with the surgery. We have observed the patient for four months with no complications. We herein describe the clinical and microscopic features of a case of silicone-induced granulomas treated by surgical removal.
\end{abstract}

Korean J Otorhinolaryngol-Head Neck Surg 2015;58(6):413-6

Key Words Foreign-body $\cdot$ Granuloma $\cdot$ Silicones.

\section{서 론}

실리콘(silicone)은 규소(silicon)와 산소의 결합을 주축으로 하는 중합체를 의미한다. 실리콘은 소수성(hydrophobicity) 이며, 낮은 표면 장력을 보이고, 열이나 화학반응에 안전하며 독소나 알레르기 반응이 없는 것이 특징이다.1) 또한 항원성이 적어 신체 내에서 면역반응을 일으키지 않아 실리콘은 유방 확 대뿐만 아니라, 인공 심장 판막, 인공 관절, 혈액 투석시 동정 맥 단락술과 뇌수중시 뇌실복강 단락술(ventriculoperitoneal shunt) 등 여러 의학 분야에서 사용되었다. 특히, 액상 주입식 실리콘(liquid injectable silicone)은 신체 특정 부위에 직접 주사하는 방법으로 연부 조직의 부피 확대 같은 미용 목적으 로 널리 사용되었다. ${ }^{2}$ 그러나 실리콘 이식물로 인해 육아종 형 성, 색전증 등의 여러 가지 국소적, 전신적 부작용이 알려졌다. 본 저자들은 안면부와 경부의 주름 개선을 위해 실리콘 주사 를 맞은 후 경부에 경화성 결절과 통증을 호소하는 73 세 여성
을 치료한 경험이 있어 문헌고찰과 증례 보고하는 바이다.

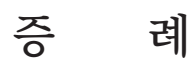

약 15 년 전 안면부와 경부에 실리콘 주사를 약 5회 맞았던 73세 여성 환자가 경부 피부가 당기고 통증이 있다면서 본원으 로 내원하였다. 이러한 증상은 약 10 년 전부터 경부에 결절이 생기면서 시작되었다고 한다. 그래서 한의원에서 금침(gold acupuncture)을 치료받기도 했으나 증상은 지속되었다. 5년 전에 는 인근 성형외과 병원에서 경부 결절 제거 수술을 받았고, 실 리콘 육아종을 진단받았다. 내원 당시 신체검사에서 안면 전체 에 부종이 있었고 안면부와 경부 주위에 약 $1 \mathrm{~cm}$ 크기의 여러 결절이 촉지되었다. 양쪽 사지에 연부조직이 굳어지고 빛을 반 사하는(glistening) 소견은 경피증(scleroderma) 같은 양상을 보 여주었다. 결절 위의 피부는 발적되어 있었고 촉지하였을 때 압 통을 호소하기도 하였다. 그러나 육아종의 표면에 피부 결손 같 

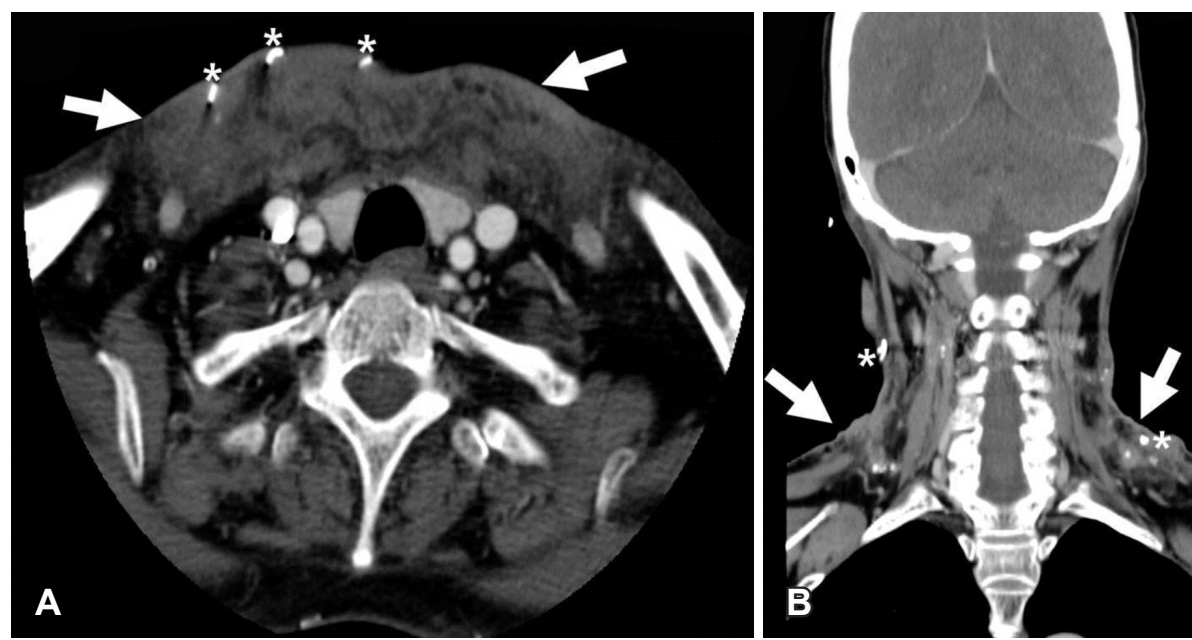

Fig. 1. CT scans (A: axial, B: coronal view). Extensive irregular asymmetric multiple nodular radio-densities in the neck (arrows). Multiple radio-opaque lesions in the neck are due to previous gold acupuncture (asterisks).

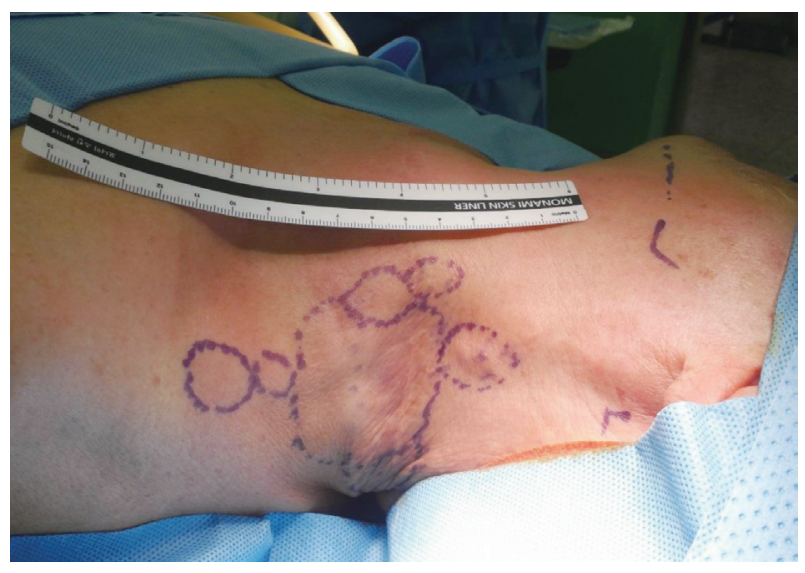

Fig. 2. Pre-operative outline of palpated left neck masses.

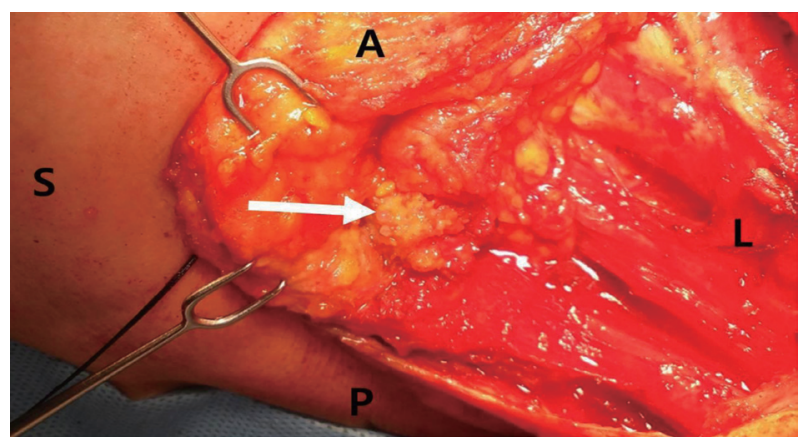

Fig. 3. Intraoperative photograph. Extensive involvement of the subcutaneous tissues with conglomerated silicone granules (arrow) and lack of clear plane between the lesions and the surrounding tissues. A: anterior, P: posterior, S: shoulder, L: left lateral neck.

은 것은 없었다. 안면부에 운동과 감각 기능에는 변화가 없었다. 실리콘 육아종으로 예비 진단하고 CT검사를 시행하였다. CT 검사에서 양쪽 경부와 양쪽 안면부에 다수의 결절이 확인되 었다(Fig. 1). 이전 타 병원에서 실리콘 육아종을 진단받은 병

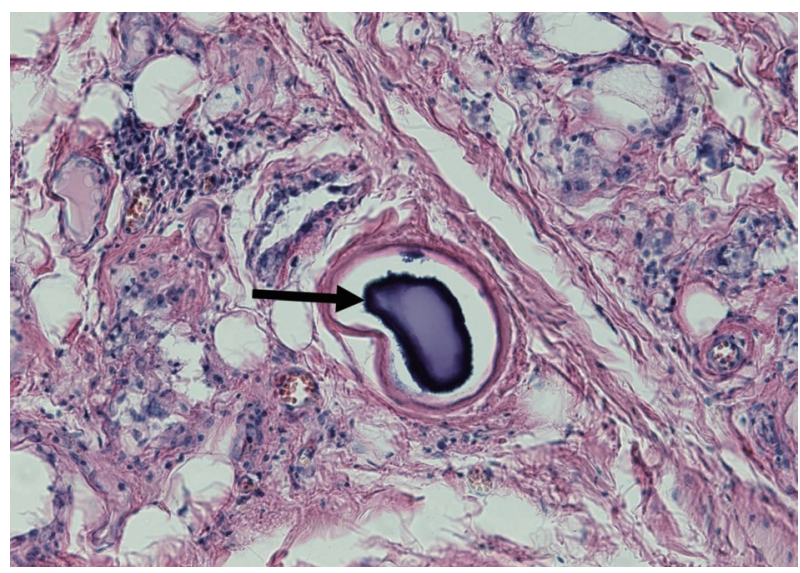

Fig. 4. Histopathologic view. There are numerous cystic spaces and vacuoles partly filled with silicone (arrow) surrounded by a thin layer of fibrous tissue (H\&E stain, magnification, $\times 200$ ).

력이 있어, 추가적인 조직검사는 시행하지 않았다. 실리콘 육아 종으로 지속적인 경부통증을 호소하여 전신마취 하에 양쪽 경 부의 림프절을 포함하여 결절을 절제하는 수술을 결정하였 다. 수술 전에 전신마취를 위한 평가에서 혈액검사, 흥부 단순 촬영검사, 호흡기능검사, 심전도검사, 소변검사에서 특이 소견 은 없었다. 술 전에 결절 부위에 바탕그림을 그리고(Fig. 2), 경부 주름 절개접근법으로 결절을 제거하였다. 결절 부위에는 실리콘 으로 추정되는 작은 용종 같은 조직이 다수 관찰되었다(Fig. 3). 조직 검사상에서는 실리콘이 들어 있는 다수의 낭성 공간과 소포(vacuole)가 얇은 층의 섬유조직으로 관찰되어 실리콘 육 아종에 합당한 소견이었다(Fig. 4). 수술 이후 2주에 봉합 부 위의 일부에서 액상 실리콘으로 추정되는 분비물이 있어 봉 합 부위에 창상회복이 지연되었다. 그래서 절개 부위를 봉합하 지 않고 열어 둔 상태에서 소독 치료를 1 주일간 시행하였더니 더 이상 분비물은 나오지 않아 절개 부위를 봉합하였다. 봉합 
한 지 1 주일 후에 외래에서 특별한 문제 없이 발사하였다. 수술 이후 경부 통증은 호전되었다. 현재 수술 이후 4개월째 특별한 합병증 없이 경과 관찰 중이다.

\section{고 찰}

실리콘은 디메틸실록산(dimethylsioloxane)의 합성 중합체 로 고체, 액체, 젤의 상태로 존재할 수 있다. 그리고 무색, 무취, 비 휘발성, 비암유발성(non-carcinogenic)이고 열에 안전하여 열 소독(heat sterilization)이 가능하고, 생화학적으로 불활성이 고, 술 전에 녹이는 작업 같은 가공과정이 필요 없어 인체 이 식물로 널리 사용될 수 있었다. ${ }^{2)}$ 이 중 액상 실리콘은 주입 방 식이 용이하여 주로 연부 조직 확대 및 주름의 교정을 위해 널 리 사용되었다. 그러나 액상 실리콘의 여러 심각한 부작용 들이 보고되었다. 국소적인 치료 부위 반응으로 동통, 홍반, 반상 출혈, 피부 변색, 경결화된 육아종겨이 이 발생하였다. 더 심각한 부작용으로 궤양, 농양 형성, ${ }^{5}$ 봉와직염, 결체조직 질 환,7, 실리콘 주입물의 이동, 고칼슘혈증을 동반한 피부 석회증 (calcinosis cutis with hypercalcemia), ${ }^{8}$ 파종상 속립성 루푸스 (lupus milliaris disseminates)," 색전증, 사망 ${ }^{4)}$ 등이 보고되었다. 이러한 부작용의 원인에 대한 다양한 보고가 있다. 첫째, 액 상 주입식 실리콘에 오염물질이 들어 있다는 것이다. 여러 연구 에서 실리콘 다당체는 건식 실리카(fumed silica), 백금, 저분 자 다당체 같은 오염물질을 포함하고 있다는 것이 입증되었 다.) 이러한 오염물질로 $\mathrm{T}$ 세포를 활성화시키고 섬유 증식증 (fibroplasia)을 일으키고 결국 실리콘 주위의 단백질을 변성 시킨다. ${ }^{2)}$ 둘째, 실리콘 입자 크기가 원인이다. 주입 물질이 작 은 입자라면 거대세포(macrophage)에 의해서 포식화되어 주 입 후 1 3개월 내에 섬유아세포에 의해서 제거되거나 콜라겐 섬유로 대체된다. ${ }^{10)}$ 그러나 만약 주입물질이 큰 입자라면 이물 질 반응이 생긴다. 거대세포에 의해서 포식이 가능한 크기는 15 micrometer 이하이다. 그러나 실리콘 입자는 170 micrometer라서 거대세포는 실리콘 입자를 포식화 하지 못한다. 그 래서 이물질에 의한 육아종이 형성되는 것이다. 셋째, 실리콘 이 생물학적으로 완벽하게 불활성을 띠는 물질이 아니라는 것 이다. 시험관 내 실험에서 인간 피부 섬유아세포(human dermal fibroblast)에 실리콘 다당체를 노출하였을 때 세포 형태 가 변하고 세포 분열이 점진적으로 감소하였다.11) 넷째, 실리콘 이 인체내에서 화학적으로 변한다는 것이다. Garrido 등리은 실리콘 다량체가 생체 내에서 분해되는 것을 핵자기공명검사 로 증명하였다. 이러한 실리콘 다량체 구조의 변화는 실리콘 입 자 간의 점성이 감소하게 되고 결국 인체의 다양한 기관으로 임 파선이나 혈관을 통해서 원거리 이동하게 된다. ${ }^{12,13)}$
진단은 먼저 CT나 MRI검사로 병변의 범위를 파악하는 것이 중요하다. ${ }^{10)}$ 본 증례에서는 조영 증강 $\mathrm{CT}$ 검사를 하였 고, 다수의 부정형의 결절이 경부와 안면부에서 관찰되었다. 실리콘 주입으로 간, 비장, 콩팥, 폐, 심장으로 이동하여 침착 할 경우 전신적인 질환이 발생할 수 있어, 혈액검사, 소변검사, 심전도, 심장 초음파 검사, 흥부 영상 검사, 폐기능검사 등이 필 요하다. ${ }^{14)}$ 확진은 조직 병리 검사로 한다. 실리콘 육아종은 조직 학적으로 아주 다양한 크기의 낭성 공간을 보이고, 그 안에 실 리콘 입자들이 관찰되는 것이 특징이다. 공간들은 비어 있거나 얇은 호산성 물질로 피복되어 있고 섬유화 반응은 심하지 않은 편이다. 낭성 공간들은 서로 융합되어 소위 눈사람 모양을 보 이기도 한다. 감별 진단으로는 단독(erysipelas), 알레르기 접촉 성 피부염, 호산구증을 동반한 안면 부종, 농양성 선상 구순염 (cheilitis glandularis apostematosa), 애셔 증후군(Ascher's syndrome), 구강안면 육아종증(orofacial granulomatosis), 크 론병, Melkersson-Rosenthal 증후군, 사르코이드증이 있다. ${ }^{1)}$

실리콘 육아종의 치료에 다양한 보고가 있다. 대개 병소 부위에 스테로이드를 주입하거나 전신적인 스테로이드 치료 를 한다. 다른 방법으로는 minocycline을 저용량 프레드니 손(low-dose prednisone)이나 celecoxib를 병합하여서 사용 하기도 한다. ${ }^{3,15}$ 이외로 imiquimod cream, ${ }^{4)}$ etanercept, ${ }^{16)}$ isotretinoin, ${ }^{17)}$ allopurinol, ${ }^{18)}$ 레이저 치료 ${ }^{19)}$ 등의 방법들이 보고되고 있다. 이러한 치료법이 효과적이지 않다면 수술적 절제를 고려 할 수 있다. 수술적 치료는 병변 부위와 범위, 환자의 기대치, 의사가 선호하는 치료법과 경험에 따라서 결정이 된다. ${ }^{10}$ 안면 부의 실리콘 육아종을 절제할 때는 절개 부위가 노출되지 않 도록 하는 것이 좋다. 특히 안면부에서 실리콘 육아종을 제거 하면 피부 함몰 등이 발생할 수 있고, 국소적 염증 반응으로 피 부의 부정형(irregularity)은 더 증가할 수 있다. 이것을 방지 하기 위해서 수술 이후 하루 2회 $100 \mathrm{mg}$ minocycline을 경구 복 용할 수 있다. ${ }^{10)}$ Minocycline은 항염증성, 면역반응조절(immunomodulating), 항육아종반응(anti-granulomatous reaction) 목적으로 사용한다. ${ }^{3,20)}$ 보고된 증례에 의하면 minocycline은 수주간 안전하게 사용할 수 있었고, 실리콘 육아종에 의한 만 성 염증성 반응을 경감시켜주었다. ${ }^{3)}$ 수술 이후 부종이 충분히 해 소되면 자가 지방(autogenous fat)으로 지방 충전술(lipo-filling technique)을 시행하여 안면부 부정형을 교정할 수 있다. ${ }^{10)}$

실리콘은 인체 내에서 비암유발성이라 증상이 없다면 경과 관찰이 가능하다. 그러나 실리콘 육아종으로 인해 만성 통증, 피부천공, 상처(scarring), 수축성 신경증(constrictive neuropathy)이 발생할 경우 수술적으로 치료할 수 있다. ${ }^{21)}$ 본 증례의 경우 육아종으로 인한 지속적인 경부 통증으로 수술적으로 치 료하였다. 
액상 주입식 실리콘 주입은 심각한 부작용으로 미국 식약 청은 1964년부터 연부 조직 확대 목적의 사용을 금지하고 있 다. 하지만 국내에서는 짧은 시간 내에 간단히 외모를 변형시킬 수 있고 비용이 싸다는 점 때문에 여전히 액상 주입식 실리콘이 불법적으로 사용되고 있는 실정이다. 코·얼굴·목에 대해 전문 적으로 치료하는 이비인후과 의사로서 이러한 이식물에 의한 합병증과 치료에 대해 잘 알 필요가 있을 것으로 생각된다.

\section{REFERENCES}

1) Ficarra G, Mosqueda-Taylor A, Carlos R. Silicone granuloma of the facial tissues: a report of seven cases. Oral Surg Oral Med Oral Pathol Oral Radiol Endod 2002;94(1):65-73.

2) Ellis LZ, Cohen JL, High W. Granulomatous reaction to silicone injection. J Clin Aesthet Dermatol 2012;5(7):44-7.

3) Arin MJ, Bäte J, Krieg T, Hunzelmann N. Silicone granuloma of the face treated with minocycline. J Am Acad Dermatol 2005;52(2 Suppl 1):53-6.

4) Baumann LS, Halem ML. Lip silicone granulomatous foreign body reaction treated with aldara (imiquimod 5\%). Dermatol Surg 2003;29 (4):429-32.

5) Schmidt-Westhausen AM, Frege J, Reichart PA. Abscess formation after lip augmentation with silicone: case report. Int J Oral Maxillofac Surg 2004;33(2):198-200.

6) Habal MB. The biologic basis for the clinical application of the silicones. A correlate to their biocompatibility. Arch Surg 1984;119(7): 843-8.

7) Lai YL, Weng CJ, Noordhoff MS. Breast reconstruction with TRAM flap after subcutaneous mastectomy for injected material (siliconoma). Br J Plast Surg 2001;54(4):331-4

8) Loke SC, Leow MK. Calcinosis cutis with siliconomas complicated by hypercalcemia. Endocr Pract 2005;11(5):341-5.

9) Suzuki K, Aoki M, Kawana S, Hyakusoku H, Miyazawa S. Metastatic silicone granuloma: lupus miliaris disseminatus facieilike facial nodules and sicca complex in a silicone breast implant recipient. Arch Dermatol 2002;138(4):537-8.

10) Anastassov GE, Schulhof S, Lumerman H. Complications after facial contour augmentation with injectable silicone. Diagnosis and treatment. Report of a severe case. Int J Oral Maxillofac Surg 2008;37 (10):955-60.

11) McCauley RL, Riley WB Jr, Juliano RA, Brown P, Evans MJ, Robson MC. In vitro alterations in human fibroblast behavior secondary to silicone polymers. J Surg Res 1990;49(1):103-9.

12) Garrido L, Pfleiderer B, Papisov M, Ackerman JL. In vivo degradation of silicones. Magn Reson Med 1993;29(6):839-43.

13) Travis WD, Balogh K, Abraham JL. Silicone granulomas: report of three cases and review of the literature. Hum Pathol 1985;16(1):19-27.

14) Brautbar N, Vojdani A, Campbell AW. Silicone implants and systemic immunological disease: review of the literature and preliminary results. Toxicol Ind Health 1992;8(5):231-7.

15) Beer K. Delayed onset nodules from liquid injectable silicone: report of a case, evaluation of associated histopathology and results of treatment with minocycline and celocoxib. J Drugs Dermatol 2009;8(10):952-4.

16) Desai AM, Browning J, Rosen T. Etanercept therapy for silicone granuloma. J Drugs Dermatol 2006;5(9):894-6.

17) Lloret $P$, España A, Leache A, Bauzá A, Fernández-Galar M, Idoate MA, et al. Successful treatment of granulomatous reactions secondary to injection of esthetic implants. Dermatol Surg 2005;31(4):486-90.

18) Redondo P, Del Olmo J, Alberola I. In situ and distant foreign body granulomas caused by silicone. Treatment with allopurinol. Br J Dermatol 2005;152(5):1064-5.

19) Chui $\mathrm{CH}$, Fong PH. Carbon dioxide laser vaporization of facial siliconomas: flash in the pan or way of the future? Ann Plast Surg 2008;60(3):272-5.

20) Senet P, Bachelez H, Ollivaud L, Vignon-Pennamen D, Dubertret L. Minocycline for the treatment of cutaneous silicone granulomas. Br J Dermatol 1999;140(5):985-7.

21) Sanger JR, Matloub HS, Yousif NJ, Komorowski R. Silicone gel infiltration of a peripheral nerve and constrictive neuropathy following rupture of a breast prosthesis. Plast Reconstr Surg 1992;89(5):949-52. 